Sachiko Kitanaka $\cdot$ Ayaka Takeda $\cdot$ Utako Sato

Yuko Miki · Akira Hishinuma · Tamio Ieiri

Takashi Igarashi

\title{
A novel compound heterozygous mutation in the thyroglobulin gene resulting in congenital goitrous hypothyroidism with high serum triiodothyronine levels
}

Received: 11 October 2005 / Accepted: 13 December 2005/Published online: 14 February 2006

(C) The Japan Society of Human Genetics and Springer-Verlag 2006

\begin{abstract}
Thyroglobulin abnormality is a rare cause of congenital hypothyroidism and only a limited number of mutations in the thyroglobulin gene have been reported. We analyzed the thyroglobulin gene in a patient with congenital goitrous hypothyroidism. This girl was identified with hyperthyrotropinemia in a neonatal mass-screening test. The patient had goiter, and her body weight gain was poor. Distal femoral epiphysis was absent on roentgenography. Her serum thyroxine level was low; however, her triiodothyronine level was high. Autoantibodies against triiodothyronine, thyroid peroxidase, and thyroglobulin were all negative. Her serum thyroglobulin level was undetectable. The thyroglobulin gene from the genomic DNA of the patient was analyzed by direct sequencing. Two novel heterozygous missense mutations, Cys1897Tyr (exon 31) and Arg2336Gln (exon 40), were found in the patient. The former mutation was derived from her mother, suggesting a compound heterozygous state. Normal triiodothyronine and low thyroxine concentrations are often observed in patients with thyroglobulin gene mutations. We considered that some patients with thyroglobulin abnormality might have high triiodothyronine levels. In cases of congenital goitrous hypothyroidism with normalto-high triiodothyronine levels and low serum
\end{abstract}

S. Kitanaka $\cdot$ A. Takeda $\cdot$ U. Sato $\cdot$ Y. Miki $\cdot$ T. Igarashi Department of Pediatrics, Graduate School of Medicine, The University of Tokyo, Tokyo, Japan

A. Hishinuma $\cdot$ T. Ieiri

Department of Clinical Laboratory Medicine,

Dokkyo University School of Medicine, Tochigi, Japan

Present address: S. Kitanaka ( $\square)$

Department of Pediatrics, Yamagata University

School of Medicine, 2-2-2 Iida-nishi,

Yamagata 990-9585, Japan

E-mail: sachi-tky@umin.ac.jp

Tel.: $+81-23-6285329$

Fax: + 81-23-6285332 thyroglobulin levels, thyroglobulin abnormality should be considered.

Keywords Thyroglobulin $\cdot$ Congenital hypothyroidism - Novel mutations · Triiodothyronine Goiter $\cdot$ Compound heterozygous

\section{Introduction}

Congenital hypothyroidism is the most common congenital endocrine disorder, occurring at a rate of 1 in 4,000 live births (Refetoff et al. 2001). Approximately $85 \%$ of patients with congenital hypothyroidism result from thyroid gland agenesis or hypoplasia, an ectopic thyroid, and are nongoitrous. The remaining $15 \%$ are goitrous, mainly due to abnormalities in thyroid hormonogenesis. This condition is associated with gene mutations in the thyroglobulin, $\mathrm{Na}^{+} / \mathrm{I}^{-}$symporter, thyroperoxidase, thyroid oxidase 2 , and pendrin genes (Refetoff et al. 2001; Medeiros-Neto et al. 1993; Moreno et al. 2002).

Thyroglobulin is a homodimeric glycoprotein of $660 \mathrm{kDa}$ synthesized by thyroid cells and secreted into the follicular lumen (Medeiros-Neto et al. 1993). Thyroglobulin functions as a matrix for triiodothyronine (T3) and thyroxine (T4) synthesis and storage. Specific tyrosyl residues on thyroglobulin are iodinated and are coupled by thyroid peroxidase to form T4 and T3. T4 is the predominant thyronine secreted by the thyroid gland, and the amount of T3 produced depends upon the iodide intake and health status of individuals. Sixty to ninety percent of $\mathrm{T} 3$ is produced by the peripheral monodeiodination of T4 by $\mathrm{D} 2$ deiodinase.

Human thyroglobulin is encoded by a large gene spanning a $270 \mathrm{~kb}$ region located on chromosome 8q24 (Mendive et al. 2001). The thyroglobulin mRNA is $8.5 \mathrm{~kb}$ long and contains 48 exons. The preprotein monomer is composed of a 19-amino-acid signal peptide 
followed by a 2,749 -residue polypeptide. The prevalence of patients with thyroglobulin defects is 1:40,000100,000 newborns. However, due to the difficulty of analyzing large genes, only nine different mutations leading to congenital goiter and hypothyroidism have thus far been identified in the human thyroglobulin gene (Ieiri et al. 1991; Targovnik et al. 1993, 1995; van de Graaf et al. 1999; Hishinuma et al. 1999; Caron et al. 2003; Gutnisky et al. 2004).

In this study, we report the analysis of the thyroglobulin gene in a patient with congenital goitrous hypothyroidism. This patient had clinical symptoms of hypothyroidism together with low serum free $\mathrm{T} 4$ and high thyrotropic hormone (TSH) levels. Interestingly, her serum free T3 and T3 levels were high before treatment. We identified a compound heterozygous mutation consisting of two novel missense mutations, in the thyroglobulin gene of this patient.

\section{Case report}

This girl was the first child of unrelated parents. Her mother had no iodide overload during pregnancy and delivery. The patient was born after induced delivery because of maternal toxemia at 38 weeks 2 days of gestation. Her birth weight was 2,664 $\mathrm{g}$ and her length was $49.0 \mathrm{~cm}$. She was referred to our hospital on day 12 because of hyperthyrotropinemia $(>100 \mathrm{mU} / \mathrm{l})$ at the neonatal mass-screening test performed on day 5 . Physical examination revealed poor weight gain, diffuse goiter, opened posterior fontanale, jaundice, slightly dry skin, and cold extremities.

Her laboratory data on day 12 revealed hyperthyrotropinemia with low free T4 and T4 levels (Table 1). However, her free T3 and T3 levels were both high (Vitros T3, Vitros FT3, Ortho-Clinical Diagnostics, Raritan, NJ). Her free T3 level was similarly high using another kit which excludes the effect of diclophenac (Vitros FT3II, Ortho-Clinical Diagnostics) (Iwahara et al. 2004). We further assayed serum free T3 and T3 levels after treatment of her serum with polyethylene glycol (PEG), to exclude the presence of interfering globulins in the serum (Sakata et al. 1985). The levels of free T3 and T3 after treatment with an equal volume of $25 \%$ PEG was no lower than those of controls (free T3 $61.1 \%$ vs. $57.3 \pm 5.8 \%$ in controls, T3 $44.3 \%$ vs.
$36.6 \pm 2.6 \%$ in controls), suggesting that there are no interfering globulins in her serum. Assay of serum autoantibody against triiodothyronine was negative. Her serum anti-thyroid peroxidase (TPO) and anti-thyroglobulin antibodies were both negative. Her serum thyroglobulin level was $<5.0 \mathrm{ng} / \mathrm{ml}$ (normal $<30 \mathrm{ng}$ / $\mathrm{ml}$ ). Echography revealed diffuse enlargement of the thyroid gland $(15 \times 18 \mathrm{~mm}$ for each lobe $)$. Bone X-ray revealed the absence of both distal femoral epiphyses. Her mother did not have a goiter, was euthyroid, had a low thyroglobulin level $(<5.0 \mathrm{ng} / \mathrm{ml})$ and was negative for thyroid autoantibodies for TPO and thyroglobulin.

The patient was diagnosed with congenital goitrous hypothyroidism and treated with $15 \mu \mathrm{g} / \mathrm{kg}$ of L-T4 orally. She became euthyroid by 1 month of age (Table 1). The level of free T3 remained high until 10 months of age when her TSH level decreased. Her growth and neurological development were normal, with a slight delay in gross motor development. She began to walk at 16 months old. No signs of hyperthyroidism were noted during the treatment course.

\section{Materials and methods}

\section{Thyroglobulin gene analysis}

Informed consent for DNA analysis was obtained from the parents. The study was performed according to the regulations of the ethical committee of Dokkyo University. Genomic DNA was extracted from peripheral white blood cells of the patient and her mother using a QIAamp blood kit (Qiagen, Hilden, Germany). PCR was performed to amplify the entire coding region and exon-intron boundaries of the thyroglobulin gene; PCR primer sequences are available on request. PCR products purified with a QIA PCR Purification kit (Qiagen) were directly sequenced using a Dye Terminator Cycle Sequencing Ready Reaction kit (Perkin-Elmer, Norwalk, CT)

\section{Results}

The direct sequencing of PCR products of the thyroglobulin gene from the patient revealed two heterozygous mutations. One of the mutations was a $G$ to $A$

Table 1 Serum thyroid hormone measurements before (12 days) and following administration of L-T4

\begin{tabular}{lccccc}
\hline & \multicolumn{2}{l}{ Age } & & \\
\cline { 2 - 6 } & 12 days & 27 days & 48 days & 1 year & Normal range (adult) \\
\hline fT3 $(\mathrm{pmol} / \mathrm{l})$ & 9.1 & 8.6 & 8.8 & 6.5 & $4.36-6.83$ \\
T3 $(\mathrm{nmol} / \mathrm{l})$ & 3.33 & 2.33 & 2.65 & 2.47 & $0.92-2.36$ \\
fT4 $(\mathrm{pmol} / \mathrm{l})$ & 3.1 & 13.3 & 29.1 & 21.6 & $11.8-22.1$ \\
T4 $(\mathrm{nmol} / \mathrm{l})$ & 19.3 & 64.2 & 127.9 & 145.4 & $73.5-130.0$ \\
TSH $(\mathrm{mU} / \mathrm{l})$ & 204 & 22.9 & 4.94 & 0.3 & $0.55-3.83$ \\
\hline
\end{tabular}


transition in exon 31 , resulting in the substitution of cysteine with tyrosine in codon 1897 (Cys1897Tyr). The other was a $G$ to A transition in exon 40, resulting in the substitution of arginine with glutamine in codon 2336 (Arg2336Gln). Repeated PCR and direct sequencing excluded the possibility that the mutation was caused by a PCR artifact. The patient's mother had a heterozygous mutation for Cys1897Tyr, whereas codon 2336 was normal. This fact suggested a compound heterozygous state in the patient. The patient's father was not analyzed.

\section{Discussion}

We have described an infant presenting with congenital hypothyroidism who was compound heterozygous for novel missense mutations in the thyroglobulin gene. We consider that this compound heterozygous mutation in the thyroglobulin gene resulted in hypothyroidism for the following reasons: (1) undetectable thyroglobulin levels in the serum in the presence of goiter, (2) the asymptomatic mother was a carrier of only one mutation, (3) these single nucleotide substitutions were not found to be polymorphic in previous reports (Hishinuma et al. 1999; van de Graaf et al. 2001).

Two novel missense mutations in the thyroglobulin gene were found in this study. Residue Arg2336 is located in the acetylcholinesterase (ACHE) homology domain (van de Graaf et al. 2001). Recently, the ACHE homology domain has been shown to be essential for the normal secretion of thyroglobulin (Park and Arvan 2004). A missense mutation in this domain in congenital goitrous hypothyroidism $\operatorname{cog} / \mathrm{cog}$ mice leads to the retention of thyroglobulin within the endoplasmic reticulum (Kim et al. 1998). There are also reports of missense mutations in this domain in humans and in $r d w$ rats (Caron et al. 2003; Hishinuma et al. 2000). There are three types of repetitive units in the thyroglobulin protein, and residue Cys1897 is located in repeated motif type 3a (Malthiery and Lissitzky 1987). Another family with an in-frame deletion mutation in this domain has been reported (Targovnik et al. 1995). The type 3 repeated motif might be important for thyroglobulin, but its function remains unknown.

Our patient had high serum T3 and free T3 levels even in the presence of low T4 and free T4 levels. From data of congenital hypothyroidism patients with free T4 levels lower than $3.9 \mathrm{pmol} / 1$ detected in the neonatal screening test, the free T3 levels were $2.6 \mathrm{pmol} / 1$ on average with a maximum of $6.8 \mathrm{pmol} / 1(n=142)(\mathrm{H}$. Inomata, personal communication): our patient therefore had an exceptionally high free T3 level. Finding such unexpected high thyroid hormone levels, methodological artifacts should be considered (Despres and Grant 1998). However, we consider that our patient's free T3 and T3 levels were truly high from the following reasons. First, an effect of diclofenac could be ruled out because the patient and her mother had no administration history and because the result was identical using an assay kit with no diclofenac interference. Second, the presence of autoantibodies might be excluded by the negative result obtained when testing for anti-T3 antibody in the patient's serum, and by appropriate free T3 and T3 levels obtained after PEG treatment. In an individual with autoantibodies, the decrease in thyroid hormone levels after treatment with PEG might be significantly higher than that of controls (Sakata et al. 1985). Third, the CLEIA method we used for free T3 assay is less affected by serum interference than RIA methods. Wells are coated with T2 gelatin to remove T3 antibodies, and bovine gamma globulin protects against heterophillic antibodies.

Some patients with thyroglobulin gene mutations have been reported with normal serum T3 levels as well as low T4 levels (Ieiri et al. 1991; Targovnik et al. 1993; van de Graaf et al. 1999; Gutnisky et al. 2004). This condition may be one of the characteristics of thyroglobulin abnormality. It is speculated that the rapid hydrolysis of limited amounts of available thyroglobulin yields adequate amounts of T3 but not T4 (Medeiros-Neto et al. 1993). It is also suspected that the conversion of $\mathrm{T} 4$ to $\mathrm{T} 3$ is activated under these conditions (Nagasaka et al. 1986). Actually, we have found that D2 deiodinase activities in the thyroid tissue of patients with thyroglobulin abnormality are significantly high (unpublished data). Furthermore, in the thyroglobulin protein, the consensus amino acid sequences for T4 and T3 synthesis are different (Lamas et al. 1989). We speculate that one or both of the mutant thyroglobulins of our patient affect only the site of T4 synthesis and do not affect synthesis of T3. Accordingly, T3 may be excessively synthesized in the state of hyperstimulation resulting from exaggerated secretion of thyrotropin. Further molecular study of these and other reported mutants might contribute to the understanding of structure-function relationships and the origin of $\mathrm{T} 3$.

It has been reported that in patients with thyroglobulin abnormality and normal T3 levels, T3 can prevent peripheral hypothyroidism (Medeiros-Neto et al. 1993). However, hypothyroidism was apparent in our patient, as represented by the absence of bone formation. It is possible that the high T3 level was transient and presented only after birth, or that T3 has only a weak function in bone maturation. It is also considered that non-functional metabolites that are cross-reacting with the T3 assays are produced by the abnormal thyroglobulin in this patient. However, the mechanism by which our patient presented with hypothyroidism in the presence of high T3 levels remains to be further investigated.

In conclusion, we reported a patient with thyroglobulin mutation, who has high T3 levels instead of low T4 and high TSH levels. Thus, in cases of congenital goitrous hypothyroidism with normal-to-high T3 levels and low serum thyroglobulin levels, thyroglobulin abnormality should be considered. 
Acknowledgements We thank Dr. H. Inomata and Dr. H. Niimi for helpful discussions. We also thank Dr. T. Ito (Ortho Clinical Diagnostics) for assay with PEG treatment. This work was supported by a Grant-in-Aid from the Ministry of Health and Welfare of Japan, and from the Ministry of Education, Science, Sports, and Culture of Japan.

\section{References}

Caron P, Moya CM, Malet D, Gutnisky VJ, Chabardes B, Rivolta CM, Targovnik HM (2003) Compound heterozygous mutations in the thyroglobulin gene (1143delC and $6725 \mathrm{G}-\mathrm{A}$ [R2223H]) resulting in fetal goitrous hypothyroidism. J Clin Endocrinol Metab 88:3546-3553

Despres N, Grant AM (1998) Antibody interference in thyroid assays: a potential for clinical misinformation. Clin Chem 44:440-454

Gutnisky VJ, Moya CM, Rivolta CM, Domene S, Varela V, Toniolo JV, Medeiros-Neto G, Targovnik HM (2004) Two distinct compound heterozygous constellations (R277X/IVS34$1 \mathrm{G}>\mathrm{C}$ and $\mathrm{R} 277 \mathrm{X} / \mathrm{R} 1511 \mathrm{X}$ ) in the thyroglobulin (TG) gene in affected individuals of a Brazilian kindred with congenital goiter and defective TG synthesis. J Clin Endocrinol Metab 89:646-657

Hishinuma A, Takamatsu J, Ohyama Y, Yokozawa T, Kanno Y, Kuma K, Yoshida S, Matsuura N, Ieiri T (1999) Two novel cysteine substitutions (C1263R and C1995S) of thyroglobulin cause a defect in intracellular transport of thyroglobulin in patients with congenital goiter and the variant type of adenomatous goiter. J Clin Endocrinol Metab 84:1438-1444

Hishinuma A, Furudate S, Oh-Ishi M, Nagakubo N, Namatame T, Ieiri T (2000) A novel missense mutation (G2320R) in thyroglobulin causes hypothyroidism in $r d w$ rats. Endocrinology 141:4050-4055

Ieiri T, Cochaux P, Targovnik HM, Suzuki M, Shimoda S-I, Perret J, Vassart G (1991) A 3-prime splice site mutation in the thyroglobulin gene responsible for congenital goiter with hypothyroidism. J Clin Invest 88:1901-1905

Iwahara K, Tanabe C, Maekawa M (2004) No interference by diclofenac with the new Vitros FT3II assay reagent. Clin Chem 50:2218-2219

Kim PS, Hossain SA, Park YN, Lee I, Yoo SE, Arvan P (1998) A single amino acid change in the acetylcholinesterase-like domain of thyroglobulin causes congenital goiter with hypothyroidism in the $\operatorname{cog} / \operatorname{cog}$ mouse: a model of human endoplasmic reticulum storage diseases. Proc Natl Acad Sci USA 95:99099913
Lamas L, Anderson PC, Fox JW, Dunn JT (1989) Consensus sequences for early iodination and hormonogenesis in human thyroglobulin. J Biol Chem 264:13541-13545

Malthiery Y, Lissitzky S (1987) Primary structure of human thyroglobulin deduced from the sequence of its 8448-base complementary DNA. Eur J Biochem 165:491-498

Medeiros-Neto G, Targovnik HM, Vassart G (1993) Defective thyroglobulin synthesis and secretion causing goiter and hypothyroidism. Endocr Rev 14:165-183

Mendive FM, Rivolta CM, Moya CM, Vassart G, Targovnik HM (2001) Genomic organization of the human thyroglobulin gene: the complete intron-exon structure. Eur J Endocrinol 145:485496

Moreno JC, Bikker H, Kempers MJ, van Trotsenburg AS, Baas F, de Vijlder JJ, Vulsma T, Ris-Stalpers C (2002) Inactivating mutations in the gene for thyroid oxidase 2 (THOX2) and congenital hypothyroidism. N Engl J Med 347:95-102

Nagasaka A, Nighei N, Hirooka Y, Mitsuma T, Kataoka K, Nakagawa H, Ohyama Y, Nakai A, Aono T, Iwase K, Ishizuki Y, Takayanagi T (1986) Congenital goiter sustaining normal level of serum triiodothyronine. Horm Metab Res 18:862-866

Park YN, Arvan P (2004) The acetylcholinesterase homology region is essential for normal conformational maturation and secretion of thyroglobulin. J Biol Chem 279:17085-17089

Refetoff S, Dumont J, Vassart G (2001) Thyroid disorders. In: Scriver CR, Beaudet AL, Sly WS, Valle D (eds) The metabolic and molecular bases of inherited disease, 8th edn. MacGrawHill, New York, pp 4029-4075

Sakata S, Komaki T, Nakamura S, Miura K (1985a) Measurement of free triiodothyronine in serum in the presence of autoantibodies to it. Clin Chem 31:1252-1253

Targovnik HM, Medeiros-Neto G, Varela V, Cochaux P, Wajchenberg BL, Vassart G (1993) A nonsense mutation causes human hereditary congenital goiter with preferential production of a 171-nucleotide-deleted thyroglobulin ribonucleic acid messenger. J Clin Endocrinol Metab 77:210-215

Targovnik HM, Vono J, Billerbeck AEC, Cerrone GE, Varela V, Mendive F, Wajchenberg BL Medeiros-Neto G (1995) A 138nucleotide deletion in the thyroglobulin ribonucleic acid messenger in a congenital goiter with defective thyroglobulin synthesis. J Clin Endocrinol Metab 80:3356-3360

van de Graaf SAR, Ris-Stalpers C, Veenboer GJM, Cammenga M, Santos C, Targovnik HM, de Vijlder JJM, Medeiros-Neto G (1999) A premature stop codon in thyroglobulin messenger RNA results in familial goiter moderate hypothyroidism. J Clin Endocrinol Metab 84:2537-2542

van de Graaf SAR, Ris-Stalpers C, Pauws E, Mendive FM, Targovnik HM, de Vijlder JJ (2001) Up to date with human thyroglobulin. J Endocrinol 170:307-321 